\title{
Study of cement pastes rheological behavior using dynamic shear rheometer
}

\section{Estudo do comportamento reológico de pastas cimentícias utilizando reômetro de cisalhamento dinâmico}
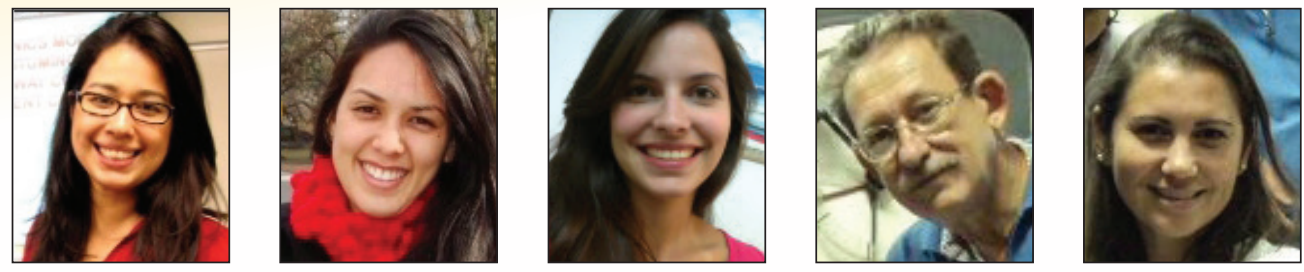

\author{
J. E. S. L.TEIXEIRA a \\ jamilla.teixeira@ufes.br \\ V. Y. SATO ${ }^{\text {a }}$ \\ yumisato2003@hotmail.com \\ L. G. AZOLIN a \\ lu_gagno@hotmail.com \\ F. A. TRISTÃO ${ }^{a}$ \\ fernandoavancini@ct.ufes.br \\ G. L. VIEIRA a \\ geilma.vieira@gmail.com \\ J. L. CALMON a \\ calmonnt@npd.ufes.br
}

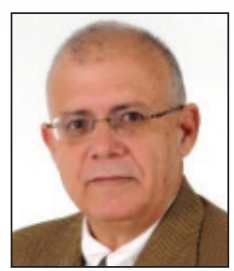

\section{Abstract}

Concrete, in its fresh state, has flow characteristics that are crucial to its proper launch and densification. These characteristics are usually measured through empirical testing as the slump test, but this test does not quantify completely the material behavior. Since this material is characterized as a Bingham fluid, it is essential the study of its rheological behavior to verify its properties even in fresh state. The use of classical rheology has been employed by the scientific community to obtain rheological parameters determinants to characterize this material, such as yield stress, plastic viscosity and evolution of shear stress to shear rate. Thus, this present study aims to determine the rheological behavior of different cement pastes produced with cement CP III 40 RS, varying between them the hydration periods ( 20 and 60 min), the water-cement ratio ( $0.40,0.45$ and 0.50 ) and the use or not of additive. Samples were assayed by flow test to determine the rheological parameters showing the effect of the variables mentioned above in these parameters.

Keywords: rheology, cement paste, viscosity, shear stress.

\section{Resumo}

O concreto, em seu estado fresco, possui características de fluidez que são determinantes para seu correto lançamento e adensamento. Estas características são geralmente medidas através de ensaios empíricos como o abatimento de tronco de cone, porém este ensaio não quantifica totalmente o comportamento do material. Sendo o material caracterizado como fluido binghamiano, é fundamental o estudo de seu comportamento reológico para a verificação de suas propriedades ainda no estado fresco. O uso da reologia clássica tem sido empregado pela comunidade científica de forma a obter parâmetros reológicos determinantes na caracterização deste material, tais como a tensão de escoamento, viscosidade plástica e evolução da tensão de cisalhamento com a taxa de cisalhamento. Dessa forma, o presente trabalho tem como objetivo verificar o comportamento reológico de diferentes pastas cimentícias produzidas com o cimento CP III 40 RS e variando-se entre elas o tempo de hidratação (20 e $60 \mathrm{~min}$ ), a relação água-cimento $(0,40 ; 0,45$ e 0,50) e com e sem incorporação de aditivo. Amostras foram ensaiadas através de ensaios de fluxo para determinação dos parâmetros reológicos, mostrando o efeito das variáveis acima mencionadas nestes parâmetros.

Palavras-chave: reologia, pasta de cimento, viscosidade, tensão de cisalhamento.

\footnotetext{
a Department of Civil Engineering, Federal University of Espírito Santo, Vitória - ES - Brasil.
} 


\section{Introduction}

It is known that Portland concrete is one of the most used materials around the world. There are several applications of this material in different areas of civil construction sector. Basically, concrete can be defined as a composite material made with hydraulic binder (Portland Cement), coarse and fine particles (aggregates), water and air, and can also contain additions and chemical additives to improve and/or modify some of its properties. The properties of this composite are directly affected by the properties of its constituents and the study of those is fundamental to determine the ideal characteristics of the concrete to be used in construction sites.

An appropriate concrete application requires, among other characteristics, good material workability. This characteristic depends on several factors, such as mixture design, equipment used to its placement, the finishing method applied, as well as the local conditions. Concrete needs to have enough cohesion and proper viscosity to make possible its transportation to the job site without having to deal with undesired situations, such as segregation of its constituents, which can affect its quality.

Therefore, concrete is a material that needs special care in all stages of its application, from the developments of specifications to its correct placement and complete cure, because many times this composite has structural function. The Brazilian standard NBR 7212 (ABNT, 1984) limits the time of transportation of concrete from mixing to its placement to a maximum of 150 minutes. If this time is exceeded, the concrete could lose workability because of water evaporation and the setting time due to the hydration process of cement particles.

To the technical control of concrete and to verify its workability in fresh state, a commonly used test is performed, the so called Slump Test, according to the Brazilian standard NBR NM 67 (ABNT, 1998). However, some concrete rheological properties, such as viscosity, shear stress, yield stress, and others cannot be obtained directly from this test. The use of better controlled equipment such as rheometers can give more precise information with respect to this fluid. Rheology is a branch of physics that studies the deformation and flow of materials, in an attempt to understand the relation among stress, rate of deformation and time. There is a concern about the mechanics of deformable bodies that can be in solid, liquid or gaseous state (MARTINS, 2004; COSTA, 2006; SCHRAMM, 2006). The study of rheology, in practice, is applied to materials that show more complex flow behavior than simple fluids (liquid and gas) or ideal elastic solids, even though, depending on the conditions in which the test is performed, the material can demonstrate simple or complex behavior (CASTRO, 2007).

According to De Larrard et al. (1996), the use of rheometers is beneficial not only to obtain a large number of parameters but also to evaluate physical quantities that may be scientific related to different stages of concrete use. Reis (2008) stated that shear stress is directly related to the results of slump tests. Another parameter evaluated is the apparent viscosity, which indicates the increment in stress that needs to be imposed to produce certain rate of deformation. In practice, the apparent viscosity is associated to the material capacity to be placed, pumped, segregated and finished, and therefore can differentiate a concrete that is workable to the one that is hard to work, having difficult pumping behavior and presenting surface voids in the structural elements when the formwork is removed (CASTRO et al., 2011).
When the workability is evaluated considering rheological parameters, the concrete production control can be made in a more accurate manner. The rheological assessment can show not only if a test result is satisfactory but also can identify the factors that can influence negatively the concrete workability during test (CASTRO, 2007).

To determine the rheological parameters of cement pastes, such as yield stress, apparent viscosity, and the effects of material consolidation associated to the hydration of cement particles, the literature suggests the use of some tests, such as the flow test, oscillatory tests (time sweep and strain sweep) and Vane tests (SATO et al., 2012; LISBÔA, 2004; CAVALCANTI, 2006; VENÂNCIO, 2008; SAAK et al., 2001; BETIOLI et al., 2009). Even though there are several studies trying to understand the behavior of concrete in its fresh state, the use of tools and tests based on rotational rheology are not many.

Concrete in its fresh state can be considered a fluid, and therefore, basic principles of rheology can be applied to this material (METHA, 1986). The main factors that cause concrete incompatibility are the amount of $\mathrm{C}_{3} \mathrm{~A}$; the type and amount of sulfates in the cement; water-soluble alkalis $(\mathrm{Na}+, \mathrm{K}+)$, either from cement particles or additives; type and design procedure of both materials, such as mineral mixtures; the cement paste temperature and the water-to-cement ratio. Some researchers related the sensibility of rheological parameters to the factors above-mentioned (FERRARIS, 1996; ZHANG, 2001; CHEN, STRUBLE, ZHANG, 2006). For the rheological analysis of cement pastes and mortars, some parameters need to be carefully defined. The time and energy spent during the mixing process for sample preparation, for example, influence significantly the rheological properties of those materials. França, Cardoso and Pileggi (2011 and 2012) mentioned that the greater the mixing time, the more efficient is the mixing process due to the high energy involved in the process, producing therefore a more disperse material (small size of mobile units, particles or agglomerates), homogeneous, stable and a more fluid like behavior. The mixing method used to produce cement pastes should simulate the shearing effects that occurs when concrete is produced. Bhattacharja and Tang (2000) also reported the use of a high shearing mixer to prepare cement pastes in order to simulate the effects of shearing.

Taking into account the need of o broader evaluation of concrete properties in its fresh state, this study aims at analyzing the rheological properties of cement pastes by performing flow test using dynamic shear rheometer as the main testing equipment. Thus, the rheological properties of pastes produced with different watercement ratios, with and without additives, will be analyzed so as to verify the effects of these constituents on rheological behavior of cement pastes.

\section{Objectives}

The present study aims at verifying the rheological behavior different cement pastes produced by mixing water and Portland cement, with and without additives, so as to assess the influence of these constituents on the study rheological parameters (yield stress, apparent viscosity, rheological profile of the material and effects of this material associated to cement hydration).

The composition of these pastes used different water-cement ratios $(0.40 ; 0.45$ and 0.50$)$, with and without additives. Also, the 


\section{Figure 1 - Granulometric curve of portland cement CP III 40 RS}

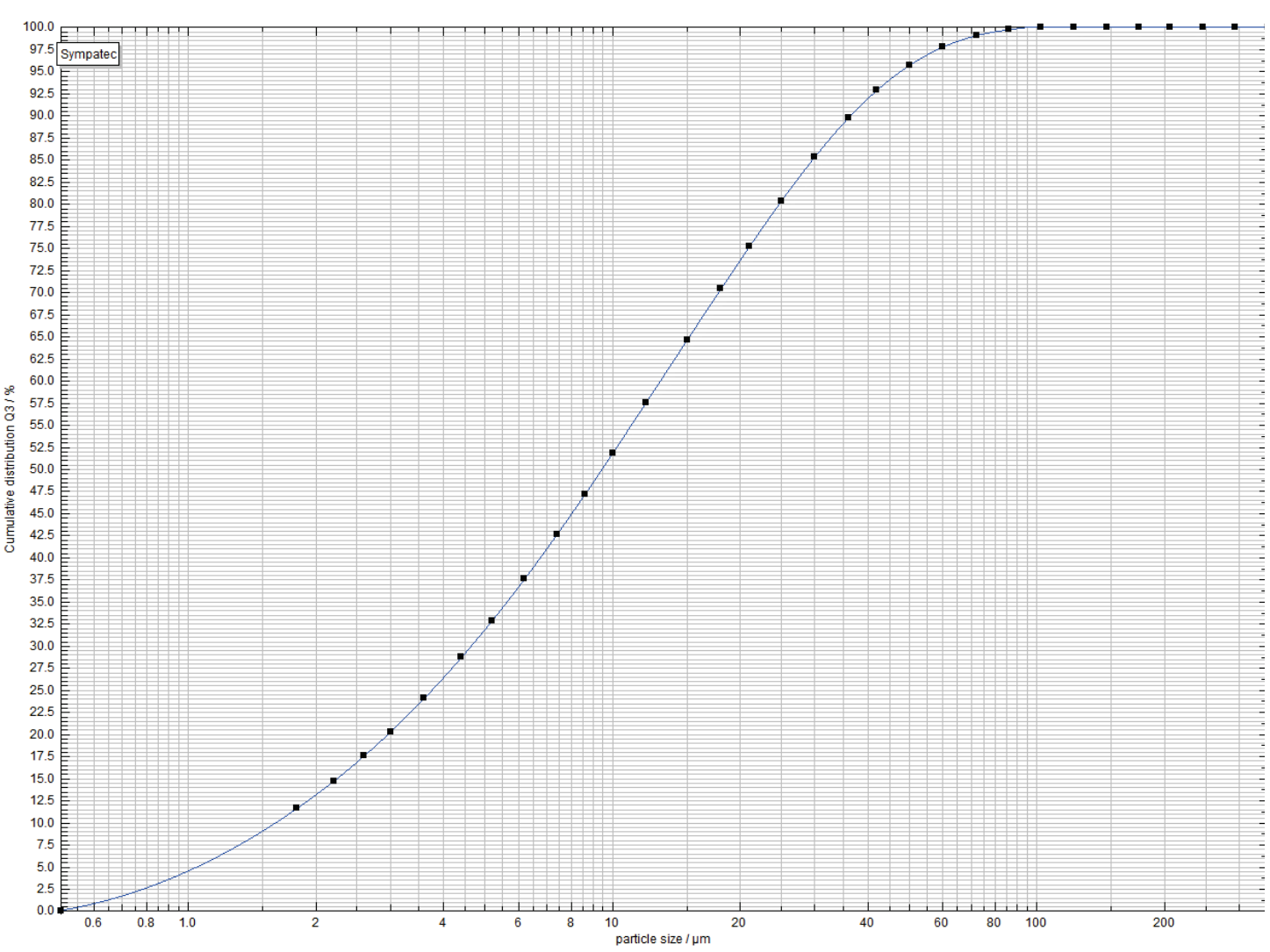

pastes were tested at different hydration times (20 and $60 \mathrm{~min}$.) in order to allow verifying the effect of cement hydration on rheological properties of the study cement pastes.

\section{Materials and methods}

\subsection{Materials}

In order to be carried out, this study used CP III 40 RS cement, classified as blast furnace Portland, resistant to sulfates as per Standard NBR 5735 (Brazilian Association of Technical Standards - ABNT, 1991). For the granulometric classification of the material, we used a laser diffraction granulometer (model Sympatec®) with lenses able to read between 1.8 to $350 \mathrm{~mm}$. Figure 1 shows the granulometric distribution curve obtained for the study cement. The additive incorporated into the study cement pastes was GLENIUM® 51 (by BASF S. A.), which is as polycarboxylate ether superplasticizer. The water used in this study was taken directly from the water concessionaire's local network.

\subsection{Composition and preparation of cement pastes}

This study analyzed samples of cement pastes with three different water/cement $(\mathrm{w} / \mathrm{c})$ ratios, with and without additives. Table 1 presents the $w / c$ ratio values and the amount of additive for each sample used in the flow test.

\subsubsection{Mixing procedures}

Since there is no standard procedure for mixing cement pastes to be used in rheological property determination using a dynamic shear rheometer, this study adopted the procedure for mixing cement pastes provided by standard NBR 13276 (ABNT, 2005), which

\section{Table $1-\mathrm{W} / \mathrm{c}$ ratios and amount of additive in the pastes analyzed}

\begin{tabular}{|ccc|}
\hline Cement paste & w/c ratio & Additive \\
\hline Paste 1 & 0.40 & - \\
Paste 2 & 0.45 & - \\
Paste 3 & 0.50 & - \\
Paste 4 & 0.40 & $0.2 \%$ \\
Paste 5 & 0.45 & $0.2 \%$ \\
Paste 6 & 0.50 & $0.2 \%$ \\
\hline
\end{tabular}




\section{Table 2 - Process of mixing materials}

\begin{tabular}{ccc|}
\hline Procedure & Initial time $(s)$ & Final time $(s)$ \\
$\begin{array}{c}\text { Putting cement } \\
\text { and water together }\end{array}$ & 0 & 30 \\
Mixer use & 30 & 60 \\
Cleaning and wait & 60 & 120 \\
Mixer use & 120 & 150 \\
\hline
\end{tabular}

concerns preparation of mix and mortar consistency index for settling and coating walls and ceilings. The mixes were determined on an electronic digital scale with $0.01 \mathrm{~g}$ accuracy. A mechanical mixer was employed to ensure homogenization of the sample.

In compliance with NBR 13276 (ABNT, 2005), first the amount of water and cement were separately weighed with $1.0 \mathrm{~g}$ approximation. Then, water was added to the specific portion of cement corresponding to the w/c under study for a continuous period of 30 seconds. After putting the materials together, they were blended in the mixer for 30 seconds, then the machine was turned off. The mixer was cleaned, we waited for 60 seconds and, finally, it was turned on again and material was mixed for another 30 seconds so as to obtain a homogeneous paste. In pastes composed also by the additive, it was added to the paste after mixing as mentioned above. The new mix was homogenized using a spatula for 30 seconds. Table 2 shows the stages for preparing the cement pastes.

After all the mixing process, the samples were kept in air-tight containers until the tests were carried. This was not to lose humidity to the ambient. Before each test, the paste was mixed again in the following way: 30 seconds using mixer, 15 seconds using spatula, and 30 seconds using the mixer again, so as to keep homogeneity.

\section{Figure 2 - Slope from 0 to 100 s -1 in 2 minutes and to 0 again in 2 more minutes (Betioli et al., 2009)}

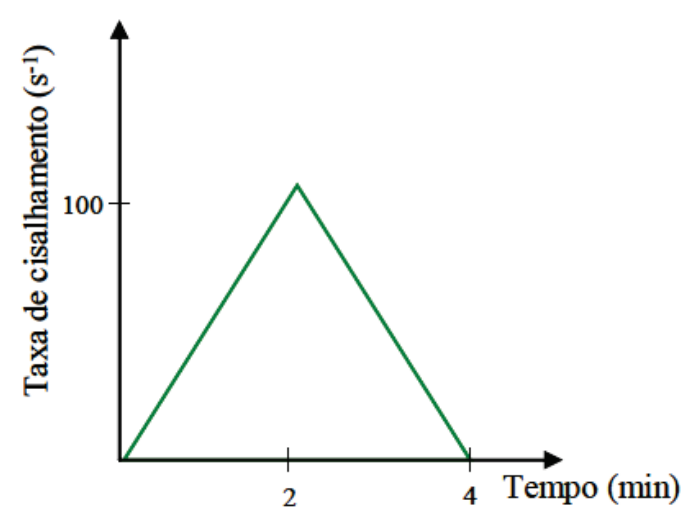

\subsection{Flow test}

Through flow-test, we can obtain shear stress at a particular shear rate. The test consists in applying an increasing shear rate with acceleration from 0 to $100 \mathrm{~s}^{-1}$ in 2 minutes, flowed by deceleration to 0 in another 2 minutes, as shown in Figure 2.

From the variation of these parameters, one can trace the rheological profile of materials, and determine important rheological properties such as apparent viscosity $\left(h_{a p}\right)$, yield stress $\left(s_{0}\right)$ and hysteresis area ( $\mathrm{AH}$, Portuguese acronym). Apparent viscosity of cement pastes was evaluated at the maximum shear rate applied, which was $100 \mathrm{~s}^{-1}$ in this study. Yield stress was approximate by extrapolating the shear stress curve and shear rate, until $0 \mathrm{~s}^{-1}$. Another parameter analyzed with flow test results was hysteresis area $(\mathrm{AH})$. This area is formed by acceleration and deceleration curves in the shear stress vs. shear rate graph (OLIVEIRA et al., 2000; BETIOLI et al., 2012), and it indicates that the level of system structuring/destructuring.

Shear cycles were carried out at pre-defined times within the cement dormancy induction interval, which shows less heat release (KIRCHHEIM, 2008). In this interval, the cement hydration reactions are considered controlled, which allows us to consider the conservation of mass at the moment of testing. Silva (2001) determined an induction period between 20 and 110 minutes from the intersection of the horizontal section with two lines: The line traced in the pre-induction period and the extrapolation of acceleration regression line, as shown in Figure 3.

Thus, the cement pastes were tested at two different cement hydration times (20 and $60 \mathrm{~min}$ ) within the material induction interval, so as to analyze the effects of cement hydration on rheological properties of cement pastes.

In order to carry out the flow tests, we used a dynamic shear rheometer. The geometry chosen for flow test was parallel-plate geometry, which has $40 \mathrm{~mm}$ diameter and $1 \mathrm{~mm}$ spacing. For

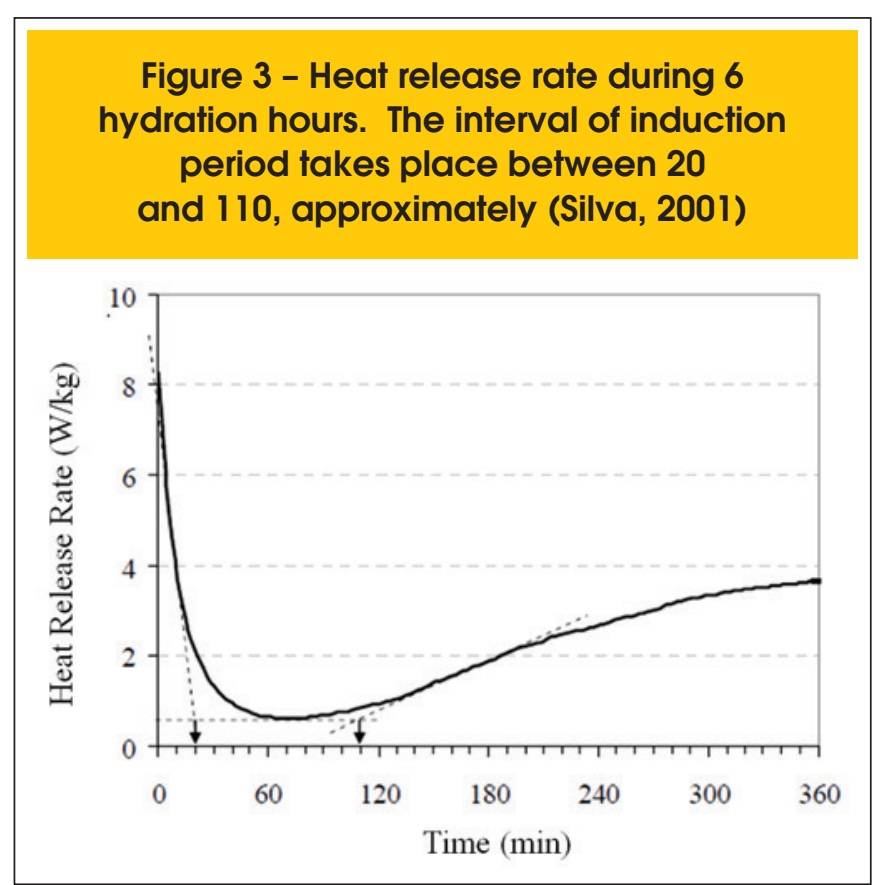


each study paste, three samples were tested. For making the shear stress vs shear rate; and viscosity vs shear rate graphs, we employed the arithmetic mean of the sample values. In the analysis of graphs, we verified the effects of water-cement ratio, additive addition, cement and hydration of rheological behavior. In order to avoid water evaporation and keep the sample temperature at $25^{\circ} \mathrm{C}$ during the test, a protective device (Peltier plate) was used. A textured sticker was applied to the surface of each plate so as to prevent the sample from slipping, as seen in Figure 4.

\section{Results and discussion}

Figures 5 and 6 show shear stress and apparent viscosity referring to shear rate for cement pastes (with and without additive) for each hydration time (20 and $60 \mathrm{~min}$ ) analyzed in this study.

One can see that the study cement pastes need an initial shear stress $(\sigma 0)$ to start yielding. After overcoming this yield stress, the pastes showed non-linear behavior, which shows a behavior tendency of a Herschel-Bulkley fluid, also known as generalized Bingham.

By analyzing the hysteresis areas between the acceleration and deceleration curves of the shear stress vs. shear rate graph, one can see that at 20 minutes of hydration, this area is virtually null. This can indicate the dispersion status of samples. Not so significant hysteresis areas little show that the mixing process adopted was enough to obtain a homogeneous sample, with total breakdown of agglomerates. On the other hand, at 60 minutes, there is a trend of restructuring of these agglomerates and, therefore, breakdown takes place during imposed shear cycles.

The action of additive is seen through the levels of shear stress in the samples. According to Oliveira et al. (2003 apud FRANÇA, CARDOSO and PILEGGI, 2012), the required levels of stress for mixing concrete are reduced when using additives, because they allow better dispersion of particles.

Figure 6 shows that for all the pastes, apparent viscosity obtained from the relationship between shear stress and shear rate decreased as shear rate increased, which shows the thixotropic nature of this material. In pastes that received additives, the addition effects on rheological behavior were evident, such as decrease in apparent viscosity, as seen in Figure 6 compared to pastes without additive (Figure 5). When adding this material, the pastes became more fluid and more susceptible to excessive deformation if submitted to shear stress. This makes measuring shear stress values more difficult using the equipment adopted in this study.

Tables 3 and 4 show the apparent viscosity and yield stress values obtained at 20 and 60 minutes of hydration, respectively.

It is seen that pastes without additive and $\mathrm{w} / \mathrm{c}$ ratio $0.40,0.45$ and 0.5 increased, respectively, of 4,9 and 7 times their yield stress at hydration age of 60 minutes compared to age 20 minutes. The increase in hydration time made pastes show a more agglomerated structure because of the process of hydrating cement particles. Therefore, more stress is required to start paste yielding. This phenomenon is reflected on the increase of yield stress. As expected, the pastes without additive showed higher yield strength compared to pastes with additive, which was also reflected on apparent viscosity of the study pastes. Addition of polycarboxylate platicizing admixtures causes cement particles to disperse, increasing flow, a phenomenon known as electrical repulsion. Thus, pastes with additives become more fluid, which results in significant reduction of yield stress and apparent viscosity values compared to pastes with the same water-cement ratio.

Figure 7 shows the correlation between yield stress and watercement obtained in this study.

We can see the trend of correlation between the parameters analyzed using exponential function, both for pastes with and without additive. Coefficients of determination $\left(R^{2}\right)$ of 0.99 and 0.96 for

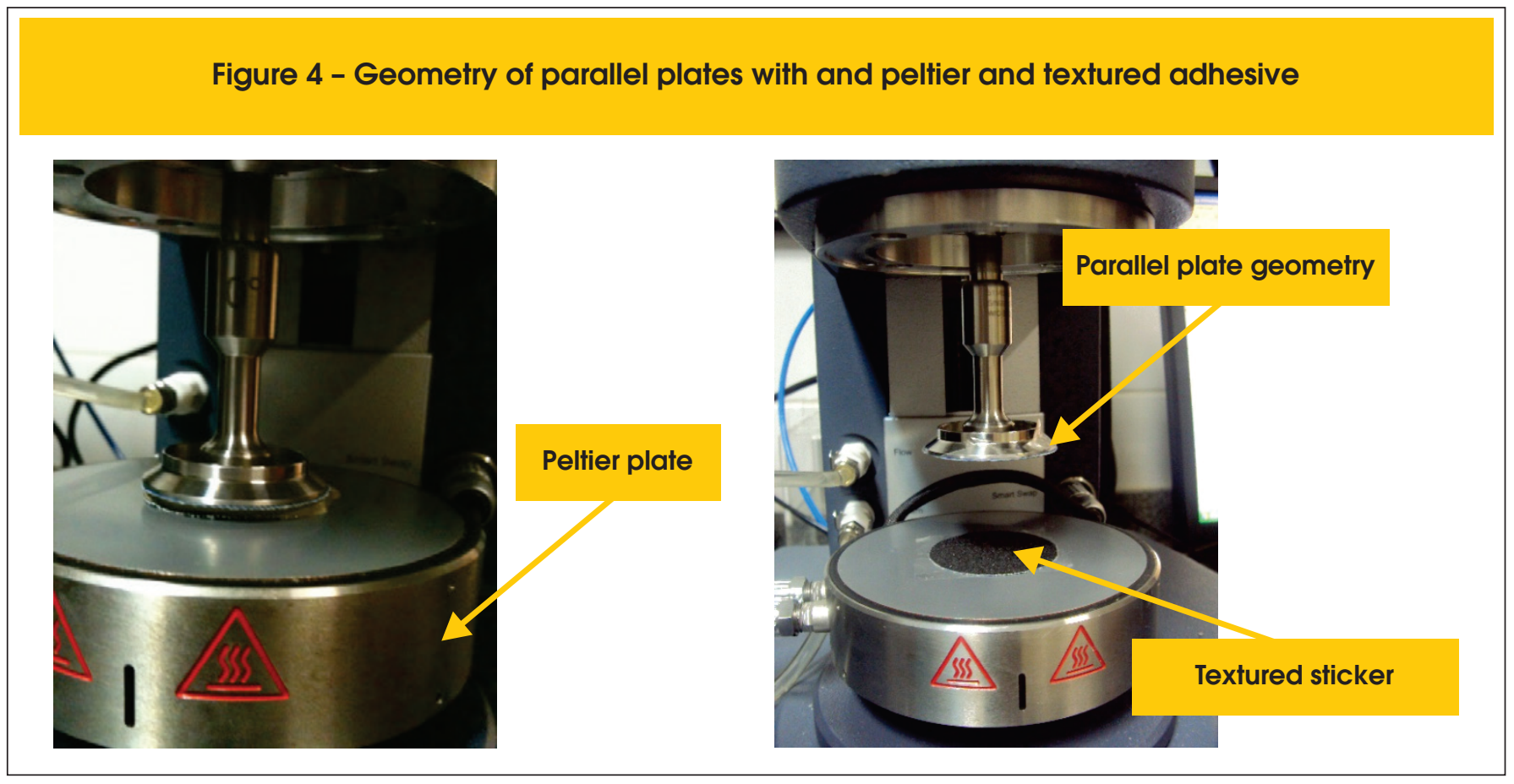


Figure 5 - Shear stress vs. shear rate in cement pastes: (a) without additive and (b) with additive, tested at hydration times 20 and 60 minutes.
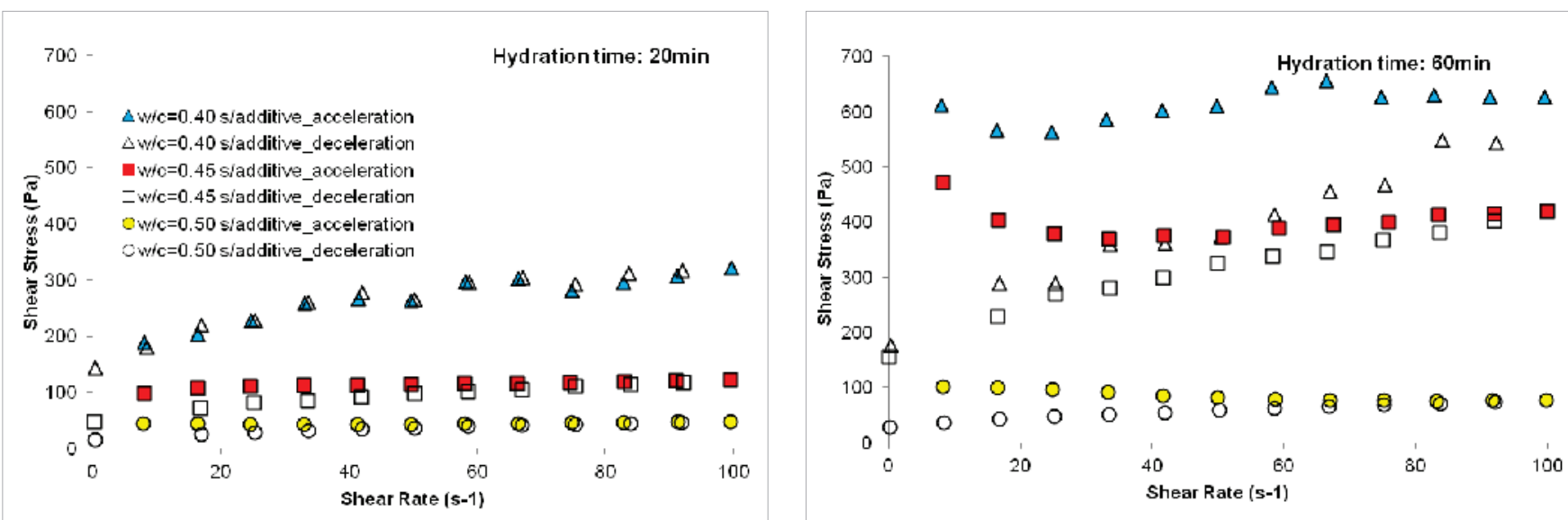

A
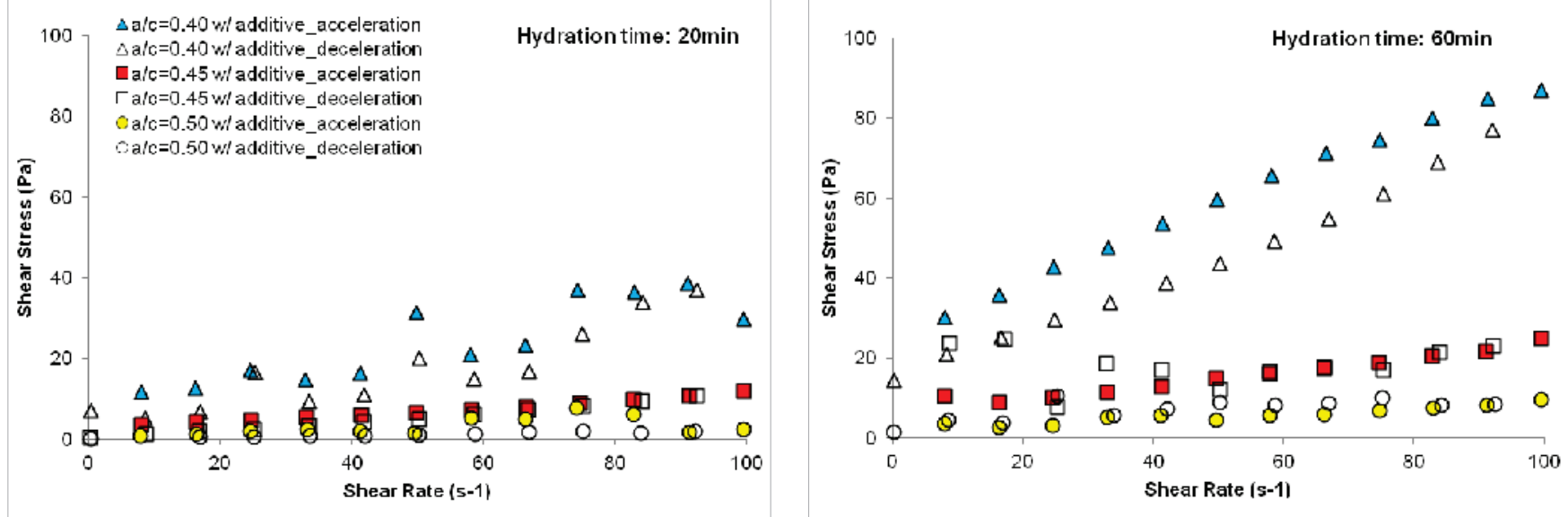

B

Table 3 - Rheological properties of cement pastes after hydration of $\mathbf{2 0} \mathrm{min}$

\begin{tabular}{|c|c|c|c|c|}
\hline \multirow{2}{*}{$w / c$} & \multicolumn{2}{|c|}{$\begin{array}{c}\eta_{\mathrm{ap}} \\
\text { (Pa.s) }\end{array}$} & \multicolumn{2}{|c|}{$\begin{array}{c}\sigma_{0} \\
\text { (Pa.s) }\end{array}$} \\
\hline & $\begin{array}{l}\text { Without } \\
\text { additive }\end{array}$ & $\begin{array}{c}\text { With } \\
\text { additive }\end{array}$ & $\begin{array}{l}\text { Without } \\
\text { additive }\end{array}$ & $\begin{array}{c}\text { With } \\
\text { additive }\end{array}$ \\
\hline 0.4 & 3.2 & 0.29 & 143 & 8.5 \\
\hline 0.45 & 1.2 & 0.11 & 47 & 2.48 \\
\hline 0.5 & 0.48 & 0.02 & 15 & 0.2 \\
\hline
\end{tabular}

Table 4 - Rheological properties of cement pastes after hydration of $60 \mathrm{~min}$

\begin{tabular}{|c|c|c|c|c|}
\hline \multirow{2}{*}{$w / c$} & \multicolumn{2}{|c|}{$\begin{array}{c}\eta_{\mathrm{ap}} \\
(\text { Pa.s) }\end{array}$} & \multicolumn{2}{|c|}{$\begin{array}{c}\sigma_{0}-\text { Acceleration } \\
\text { (Pa.s) }\end{array}$} \\
\hline & $\begin{array}{l}\text { Without } \\
\text { additive }\end{array}$ & $\begin{array}{c}\text { With } \\
\text { additive }\end{array}$ & $\begin{array}{l}\text { Without } \\
\text { additive }\end{array}$ & $\begin{array}{c}\text { With } \\
\text { additive }\end{array}$ \\
\hline 0.4 & 6.3 & 0,87 & 576 & 27 \\
\hline 0.45 & 4 & 0.2 & 441 & 8 \\
\hline 0.5 & 0.8 & 0.1 & 100 & 3 \\
\hline
\end{tabular}


pastes without and with additives, respectively, show strong negative correlation between yield stress and water-cement ratio. The use of this type of correlation, based on analysis of rheological parameters can lead to measuring workability in a more scientific way.

\section{Conclusions}

In order to better understand the influence of important variable in dosing cement mixes (w/c ratio, cement hydration, and use of chemical admixtures) on cement-based materials, we adopted rheological tests. The rheological behavior of cement pastes is complex because many factors interfere in their properties, such as type of cement and its reactive nature, water-cement ratio used, presence of additives, and mixing conditions (speed, length, confinement), among others. The flow test is an effective tool to determine rheological proper- ties of cement pastes in laboratory, because it is possible to induce samples to a high shearing magnitude. This resulted in different values of rheological properties (apparent viscosity and yield stress). Apparent viscosity showed to be higher in pastes with lower watercement ratio among the samples without additive. The pastes using additive showed apparent viscosity with little variation.

Yield stress for pastes without additives increased significantly with hydration age.

This study shows the need of further investigations on rheological characterization of cement pastes due to the large range of products that can be used to produce them.

\section{Acknowledgements}

The authors are grateful to Capes (Coordination for the

Figure 6 - Apparent viscosity vs. shear rate in cement pastes: (a) without additive and (b) with additive, tested at hydration times $\mathbf{2 0}$ and $\mathbf{6 0}$ minutes
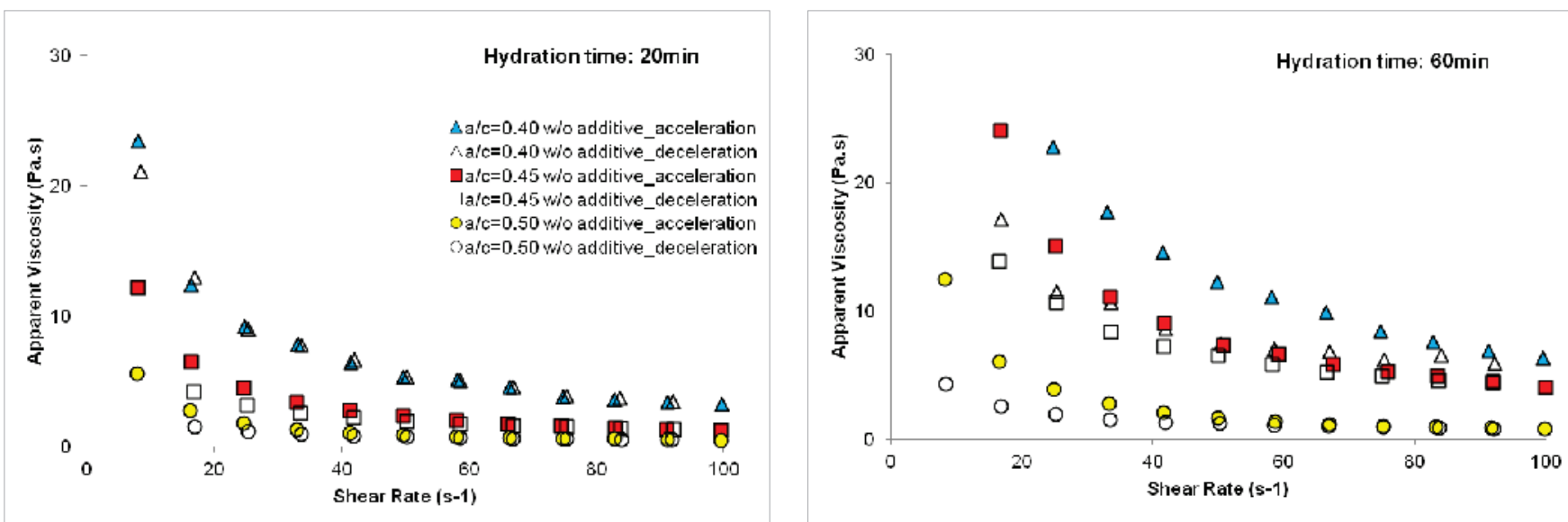

A
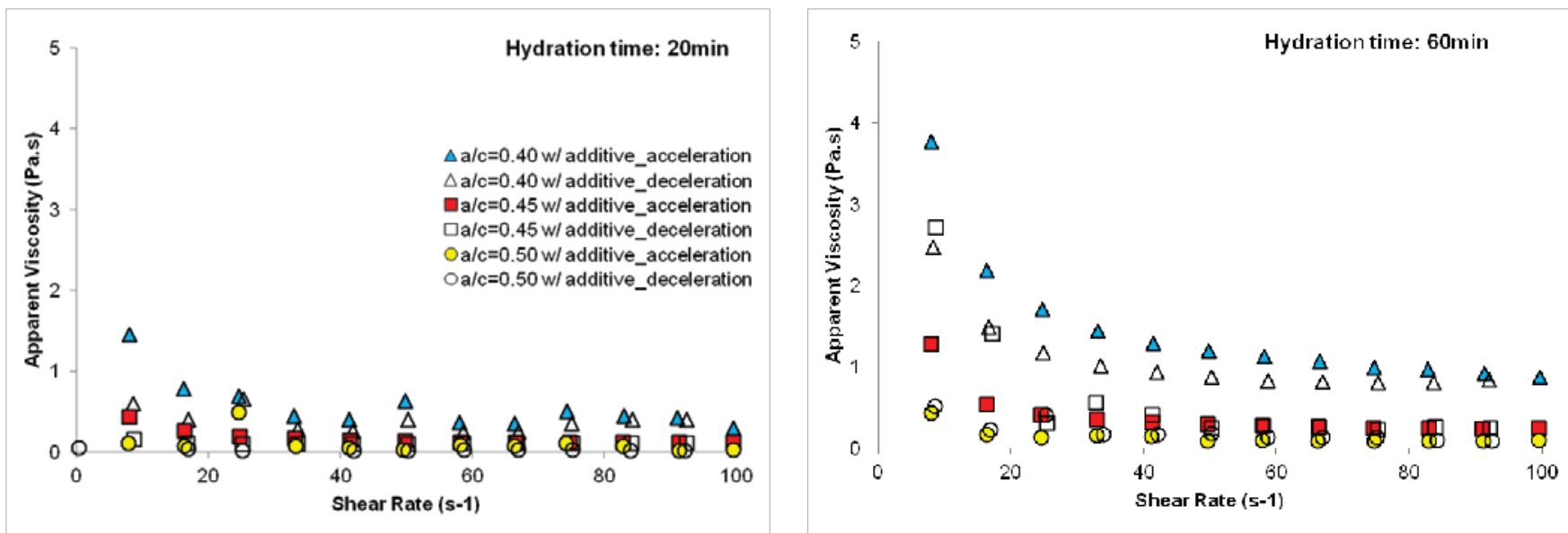


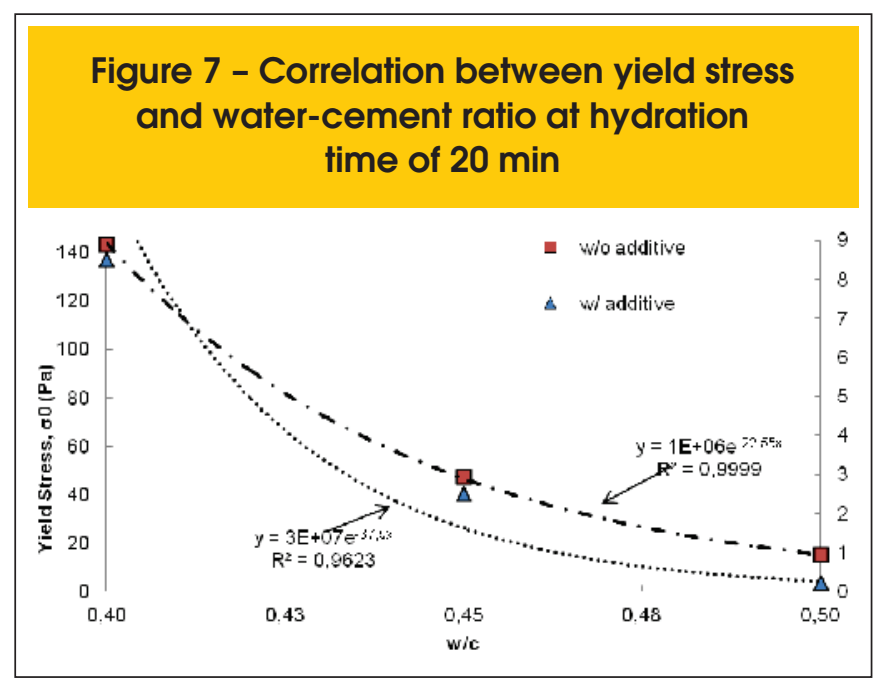

Improvement of Higher Education Personnel) and CNPq (Brazilian National Council for Scientific and Technological Development) for financial support, and to Laboratório de Ensaios em Materiais de Construção-LEMAC (Laboratory for Testing Construction Materials) at Technology Center at Federal University of Espírito Santo (UFES), Brazil for their technical support and infrastructure for carrying out this study.

\section{References}

[01] ASSOCIAÇÃO BRASILEIRA DE NORMAS TÉCNICAS. NBR 13276: Preparo da mistura e determinação do índice de consistência da argamassa para assentamento e revestimento de paredes e tetos, 2005.

[02] NBR 5735: Cimento Portland de Alto Forno. Rio de Janeiro, 1991.

[03] _ NBR 7212: Execução de concreto dosado em central. Rio de Janeiro, 1984.

[04] _. NBR NM 67: Concreto - Determinação da consistência pelo abatimento do tronco de cone. Rio de Janeiro, 1998.

[05] BARNES, H. A.; HUTTON, J. F.; WALTERS, K. An introduction to rheology. 3. ed. Amsterdam: Elsevier, 1993.

[06] BETIOLI, A. M.; JOHN, V. M.; GLEIZE, P. J. P., PILEGGI, R. G. Caracterização reológica de pasta cimentícia: associação de técnicas complementares. Ambiente Construído, Porto Alegre, v. 9, n. 4, p. 37-48, out./dez. 2009.

[07] BETIOLI, A. M. , GLEIZE, P. J. P., JOHN, V. M. , PILEGGI, R. G. Effect of EVA on the fresh properties of cement paste. Cement \& Concrete Composites Vol. 34, 255-260, 2012.

[08] BHATTACHARJA, S.; TANG, F. J. Rheology of cement paste in concrete with different mix designs and interlaboratory evaluation of the mini-slump cone test, PCA R\&D, Serial No. 2412, Portland Cement Association, Skokie, Illinois, 2000.

[09] CASTRO, A. L. Aplicação de conceitos reológicos na tecnologia dos concretos de alto desempenho. 2007. 302f. Tese (Doutorado) - Escola de Engenharia de São Carlos / Instituto de Física de São Carlos/ Instituto de Química de São Carlos - Universidade de São Paulo, São Carlos, 2007.

[10] CASTRO A. L., LIBÓRIO J. B. L., PANDOLFELLI V. C. Reologia de concretos de alto desempenho aplicados na con- strução civil - Revisão. Revista Cerâmica, São Carlos, v. 57, p. 63-75, 2011.

[11] CAVALCANTI, D. J. H. Contribuição ao estudo de propriedades do concreto auto-adensável visando sua aplicação em elementos estruturais. 2006. 141f. Dissertação (Mestrado) - Programa de Pós-Graduação em Engenharia Civil, Universidade Federal de Alagoas, Maceió, 2006.

[12] CHEN, C.; STRUBLE, L. J.; ZHANG, H. Using dynamic rheology to measure cement-admixture interactions. Journal of ASTM International, West Conshohocken, v. 3, mar. 2006.

[13] COSTA, M. R. M. M. Análise comparativa de argamassas colantes de mercado através de parâmetros reológicos. 2006. 131f. Tese (Doutorado) - Escola Politécnica da Universidade de São Paulo, São Paulo, 2006.

[14] De LARRARD, F.; SEDRAN, T.; HU, C.; SZITKAR, J. C.; JOLY, M.; DERKX, F. Evolution of the workability of superplasticized concretes: assessment with the BTRHEOM rheometer. In: International Rilem Conference - Production Methods and Workability of Concrete, 1996, Paisley/Scotland. Proceedings... London: E \& FN Spon, 1996, p. 377-388.

[15] FERRARIS, C. F.. Measurements of rheological properties of high performance concrete: state of the art report. Journal of Research of the National Institute of Standards and Technology, Gaithersburg, v. 104, n. 5, p. 461-478, 1996.

[16] FRANÇA, M. S.; CARDOSO, F. A.; PILEGGI, R. G. Avaliação do comportamento de mistura de argamassas através de reometria rotacional. Ambiente Construído, v. 12, n. 2, p. 165-174, 2012.

[17] FRANÇA, M. S.; CARDOSO, F. A.; PILEGGI, R. G. Influência do tempo de mistura nas propriedades reológicas de argamassas. In: Simpósio Brasileiro de Tecnologia de Argamassas, 9., 2011, Belo Horizonte. Anais... Belo Horizonte: SBTA, 2011.

[18] GHIO, V. A.; MMONTEIRO P. J.; DEMSETZ, L. A. The rheology of fresh cement paste containing polysaccharide gums. Cement Concrete Research, Philadelphia, v. 24, n. 2, p. 243249, 1994.

[19] HACKLEY, V. A.; FERRARIS, C. F. Guide to rheological nomenclature: measurements in ceramic particle systems. NIST special publication, v. 946, 2001.

[20] KIRCHHEIM, A.P. Aluminatos tricálcicos cúbico e ortorrômbico: análise da hidratação in situ e produtos formados. 2008. 265f. Tese (Doutorado) - Programa de Pós-Graduação em Engenharia Civil, Universidade Federal do Rio Grande do Sul, Porto Alegre. 2008.

[21] LISBÔA, E. M. Obtenção do concreto auto-adensável utilizando resíduo do beneficiamento do mármore e granito e estudo de propriedades mecânicas. 2004. 121f. Dissertação (Mestrado) - Programa de Pós-Graduação em Engenharia Civil, Universidade Federal de Alagoas, Maceió, 2004.

[22] MARTINS, A. L. P. Estudo das propriedades reológicas do muco brônquico de pacientes sob fisioterapia respiratória. 2004. 70f. Dissertação (Mestrado) - Programa de Pós-Graduação em Fisioterapia. Universidade Federal de São Carlos, São Carlos, 2004.

[23] METHA, P. K. Concrete: structure, properties, and materials. Prentice-Hall, Inc, Englewood Cliff, New Jersey, p. 449, 1986.

[24] NONAT, A.; MUTIN, J. C.; LECOQ, X.; JIANG, S. P. Physicochemical parameters determining hydration and particle in- 
teractions during the setting of silicate cements. Solid State Ionics, v. 101-103, n. 2, p. 923-930, nov. 1997.

[25] OLIVEIRA, I. R., STUDART, A. R., PILEGGI, R. G., PANDOLFELLI, V. C. Dispersão e empacotamento de partículas: Princípios e aplicações em processamento cerâmico. Fazendo Arte Editorial. 2000.

[26] RAMACHANDRAN, V. S.; BEAUDOIN, J. J. Handbook of analytical techniques in concrete science and technology: principles, techniques, and applications, Book 2001.

[27] REIS, J. F. A. Determinação de parâmetros reológicos de concretos através do ensaio de abatimento de tronco de cone modificado: estudo de caso. 2008. 177f. Dissertação (Mestrado) - Programa de Pós-Graduação em Engenharia Mecânica, Universidade Estadual Paulista, Ilha Solteira, 2008.

[28] SAAK, A. W.; JENNINGS, H. M.; SHAH, S. P. The influence of wall slip on yield stress and viscoelastic measurements of cement paste. Cement and Concrete Research, Philadelphia, v. 31, n. 2, p. 205-212, fev. 2001.

[29] SATO, V. Y.; EVANGELISTA, K. T. C.; TEIXEIRA, J. E. S. L.; TRISTÃO, F. A. Estudo das propriedades reológicas de pastas de cimento de concretos bombeados. In: Congresso Brasileiro do Concreto, 54., 2012, Maceió. Anais... Maceió: IBRACON, 2012.

[30] SCHRAMM, G. Reologia e reometria: fundamentos teóricos e práticos. 2. ed. São Paulo: Artiliber, 2006.

[31] SILVA, D. A. Efeitos dos polímeros HEC e EVA na microestrutura de pastas de cimento portland. 2001. 246f. Tese (Doutorado em Ciência e Engenharia dos Materiais) - Departamento de Engenharia dos Materiais, Universidade Federal de Santa Catarina, Florianópolis, 2001.

[32] TATTERSALL, G.H.; BANFILL P.F.G. The Rheology of Fresh Concrete, Pitman, p. 356, 1983.

[33] VENÂNCIO, P. B. F. Dosagem de argamassa para estaca raiz. 2008. 173f. Dissertação (Mestrado) - Departamento de Engenharia Civil e Ambiental, Universidade de Brasília, Brasília, 2008.

[34] ZHANG, H. Using Dynamic Rheology to Explore the Microstructure and Stiffening of Cementitious Materials, Ph.D. Thesis, University of Illinois at Urbana-Champaign, 2001. 